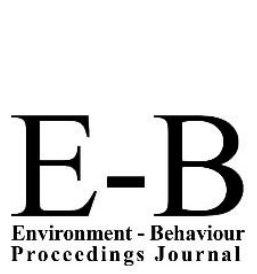

\author{
ASLI QoL 2017 \\ AQoL2017Kuching \\ http://www.amerabra.org; $h$ ttps://fspu.uitm.edu.my/cebs \\ $3^{\text {rd }}$ ABRA International Conference on Quality of Life \\ "Quality of Life 3" \\ Riverside Majestic Hotel, Kuching, Malaysia, 14-16 Oct 2017
}

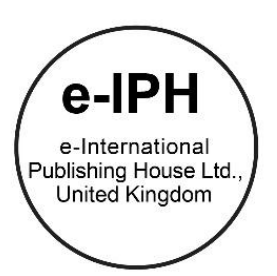

\title{
Elevated Highways and its Lost Spaces: A Review of Kuala Lumpur's seldom seen
}

\author{
Mohamed Ikhwan Nasir Mohamed Anuar, Raziah Ahmad \\ Centre of Studies for Landscape Architecture, Faculty of Architecture, Planning and Surveying, \\ Universiti Teknoolgi MARA Kampus Puncak Alam, Malaysia. \\ ikhwannasir@salam.uitm.edu.my \\ Tel:+60182323391
}

\begin{abstract}
The development of the urban highway in and around the city has created vast quantities of left over spaces that seldom integrated into formal planning and design. Vague on purpose, the interstitial spaces formed from these concrete "rivers" are referred as lost spaces. This paper aims to explore the urban interstices and investigate its possible usage. Site observation and photographic recordings of a case study were employed. The site characteristics were recorded in which findings suggested that the interstitial spaces have the potential to be planned and designed to cater adjacent community needs and usage.
\end{abstract}

Keywords: Elevated Highways; Interstitial Spaces; Lost Spaces; Possible Usage

eISSN: 2398-4287C 2017. The Authors. Published for AMER ABRA by e-International Publishing House, Ltd., UK. This is an open access article under the CC BYNCND license (http://creativecommons.org/licenses/by-nc-nd/4.0/). Peer-review under responsibility of AMER (Association of Malaysian Environment-Behaviour Researchers), ABRA (Association of Behavioural Researchers on Asians) and cE-Bs (Centre for Environment-Behaviour Studies), Faculty of Architecture, Planning \& Surveying, Universiti Teknologi MARA, Malaysia.

https://doi.org/10.21834/e-bpj.v2i6.966

\subsection{Introduction}

This conceptual paper explores the potential and suggests possible usage of the often overlooked left over spaces that are the byproduct of elevated urban highways. As the number of private vehicles rises and urban area expands so does demand for better connectivity. The increase in demand thus drives the development of roadways within the urban area primarily the construction of highways. Following this, transportation infrastructure is one of the major drivers of landscape change worldwide (Bürgi et al. 2004; Forman et al. 2003; Meyer and Turner 1994). Landscape fragmentation caused by transportation infrastructure has some effects on almost all components of landscapes, including aesthetic, ecological, historical, and recreational qualities (Forman et al. 2003; National Research Council 2002; Canters,1995;). The development of high-performance infrastructure particularly highways that dissect though urban spaces have resulted in the formation of empty and leftover spaces.

The spaces along and under elevated highways affect the way we experience the city. They disconnect neighbourhoods, produce undesirable views, and act as physical and psychological barriers making the pedestrian experience unpleasant (Trancik, 1986). Adding to this, the unclear territoriality of these spaces sometimes leads to land misuses such as dumping debris, abandoning of cars, or illegal activities (Hamersma et al., 2017; Shoaib and Ghendy, 2013; Mohamad and Kiggundu, 2007; Nor, 2001; Gee, 2002; Trancik, 1986). The inappropriate use of the vacant spaces under elevated highways might lead to social and economic problems in addition to being unsightly and lowering the value of adjacent properties (Halprin, 1966).

Elevated highways are described as pieces of infrastructure which seldom attract people's affection and pose a constant provocation, although practical and financial reasons suggest to simply accepting their presence. (Harnack and Cohler, 2011).

eISSN: 2398-4287C 2017. The Authors. Published for AMER ABRA by e-International Publishing House, Ltd., UK. This is an open access article under the CC BYNCND license (http://creativecommons.org/licenses/by-nc-nd/4.0/). Peer-review under responsibility of AMER (Association of Malaysian Environment-Behaviour Researchers), ABRA (Association of Behavioural Researchers on Asians) and cE-Bs (Centre for Environment-Behaviour Studies), Faculty of Architecture, Planning \& Surveying, Universiti Teknologi MARA, Malaysia.

https://doi.org/10.21834/e-bpj.v2i6.966 
Following this, Crisman, (2012) stated that the resulting interstice, "a space that intervenes between one thing and another," often generates seemingly uninhabitable zones and problematic discontinuities in the physical and social fabric. Issues relating to the formation and unclear function of these lost spaces has mostly been discussed in the western world and still limited within surrounding region (Sanches and Pellegrino, 2016; Clements, 2013; Qamaruz-Zaman et al., 2013; Hormingo and Morita, 2004).

\subsection{Issues, aim and objective of study}

Scholars, designers and planners, spanning multiple fields of practice, have noted that the issue is a result from of a lack of integration during the planning and design process, and that the problem of left over spaces is indeed a gap that is to be addressed (Akinci et al., 2016; Prasetyo \& Iverson 2014; Crisman, 2009, Mossop, 2006; Trancik, 1986). Barter's study (2004) disclosed significant issues about highways in Kuala Lumpur which demonstrates the high ratio of highways as compared to the number of population (68 meters per 1000 population). Therefore, to address the issues at hand, there is a need to understand the current situation of the existing leftover spaces which is the aim of this paper. Based on the stated aim, the objective of the study is to assess the typologies of spaces and its characteristics underneath elevated highway based on available literature as well as to explore the possibilities of usage for spaces underneath the elevated highway.

\subsection{Literature Review}

Since, the 1950s, scholars' and researchers' interest in urban highways and its impact on urban fabric has become prominent in both academic and popular culture writings. One prominent example was the movie "Citizen Jane: Battle for the City" which was opened on April 21, 2017 (Lawson, 2017). This rousing documentary was about journalist-activist, Jane Jacobs and her fight against elevated highways in New York City in the 1960s. The following section provides insight into topics related to elevated highways as studied and investigated by previous researchers.

\subsection{The Traditional and Modern City Planning}

Discussion on urban highways would not be completed without referring to urban form and city planning. Urban highways were not present in the traditional urban form. As shown in Figure 1, administrative and commercial buildings as well as public spaces in the traditional city were designed near to each other. Such layout would encourage walking activities as well as promote non-dependency on automobile and highways.

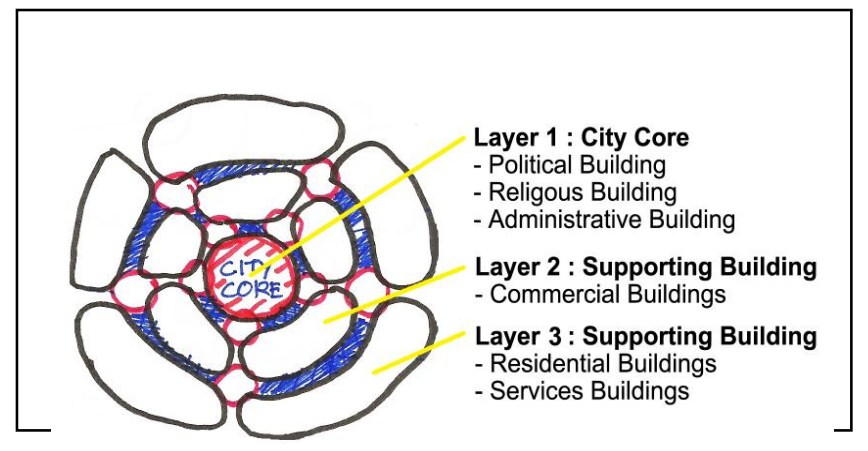

Fig. 1: The conceptual layout of traditional city (Source: Sahabuddin, 2011)

Pu Miao (1990) has conducted an interesting study on the traditional urban form in Southeast China which explains the conceptual layout of a traditional city. She made a comparison of the characteristics of the layout of the traditional city in Southeast China and Western cities. Her findings revealed that the major circulations routes-streets and canals tended to form an orthogonal, symmetrical network such as "+" and "T". The most important street often ran north to south. Meanwhile, the "square" or "rectangular" is a type of space represented in the plaza or places of European medieval and Renaissance cities.

Interestingly, as shown in Figure 2, the urban form of Kuala Lumpur illustrates Pu Miao's findings. It reflects the hybrid of the Eastern and Western style of urban form. Chinatown was developed by Yap Ah Loy, the Chinese Kapitan in mid 19th Century, while in the late $19^{\text {th }}$ century, the administrative centre around Sultan Abdul Samad Building was reformed by Sir Frank Swettenham (Gullick, 2000). During the British Colonial Era, urban dwellers in Kuala Lumpur were non-automobile dependency. The walking distance between the administrative centre and the commercial area of Chinatown have eased pedestrian to move around. 


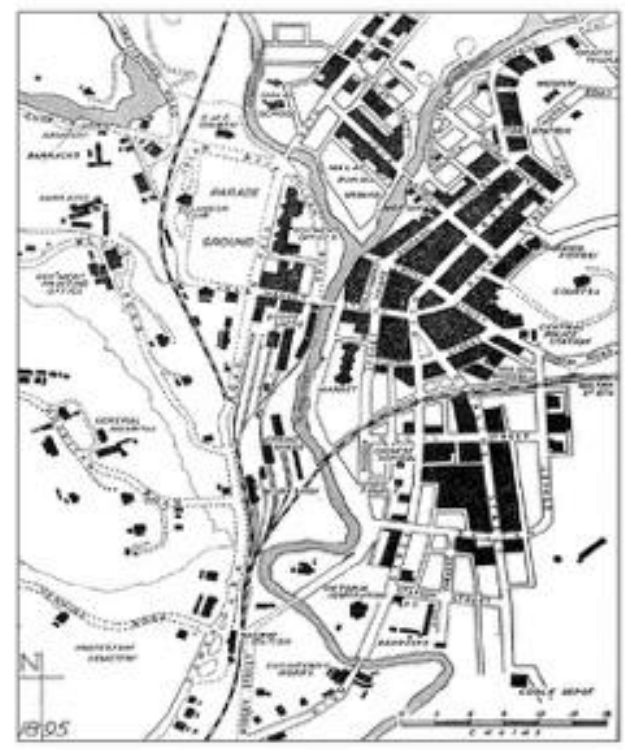

Fig. 2: Map showing the meeting of Chinatown commercial district and the administrative centre around Sultan Abdul Samad Building at the confluence of Klang and Gombak Rivers

(Source: https://assets.nst.com.my/images/articles/0870117LTpg18pix2.transformed.jpg)

The industrial revolution was started in England in the $18^{\text {th }}$ century, and it has a great impact on city planning and urban transport around the globe. In modern city planning (some authors refer as post industrial), urban transport has become significant and integrated into urban land use planning. Jacobs, (1961) in her classic book "The Death and Life of Great American Cities' commented that the urban planners and architect -Sir Patrick Geddes, Ebenezer Howard and Le Corbusier have embraced land use zoning in city planning. For instance, great arterial road system in Corbusier's Radiant City has had an immense impact on the urban and transport planning in Europe, United States of America and Asia.

Merrilees et al. (2013) in their article, "City Branding: A Facilitating Framework for stressed Satellite Cities, discuss how workers and students travel to work in the major city and return to satellite city using congested highways. They define satellite cities as a phenomenon of population expansion, and changes in industrial bases, property development and demands for more affordable housing. Figure 3 illustrates the concept of satellite town in modern city planning. In contrast to the traditional urban fabric that promotes walking activities around cities, the zoning system in modern city planning has made urban dwellers highly dependent on urban highways.

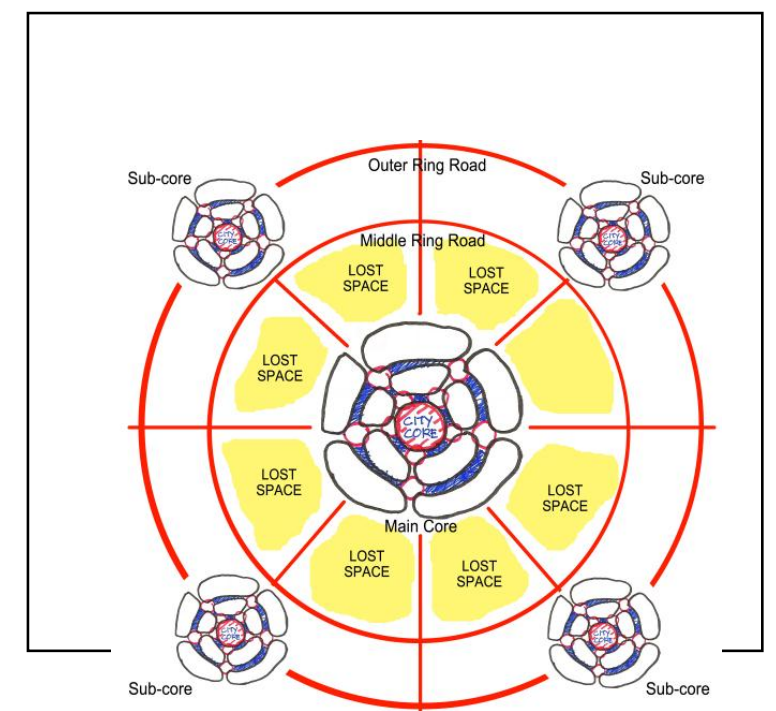

Fig. 3: The concept of satellite town in modern city planning, illustrating urban highways as important urban infrastructure that links sub-core and main core area

(Source: Sahabuddin, 2011)

After Malaysia gained independence from the British in 1957, Kuala Lumpur as a capital city has experienced rapid development that has changed the physical and social infrastructures. Petaling Jaya, Shah Alam, Putrajaya, Cyberjaya and Damansara have been 
established to support population expansion, changes in industrial bases, property development and demands for more affordable housing. According to Dasimah (2001), it evident that urban inhabitant in these satellite cities is much dependent on urban highways.

Urban highways such as the North-South Expressway (NKVE), Duta-Ulu Klang Expressway DUKE), New Pantai Expressways were constructed to facilitate urban commuters to travel to work. In this context, Mega malls often serve as major nodes between workplace and home, resulting in high dependency on urban highways for most urban residents (Figure 4). Barter (2004), provides several prominent examples of a high reliance on highways in Kuala Lumpur Metropolitan- IKEA in Cheras was established closed to MEX (The Maju Expressway), AEON Mall in Shah Alam and Mid Valley Mega Mall in Bangsar were built next to the Federal Highway.

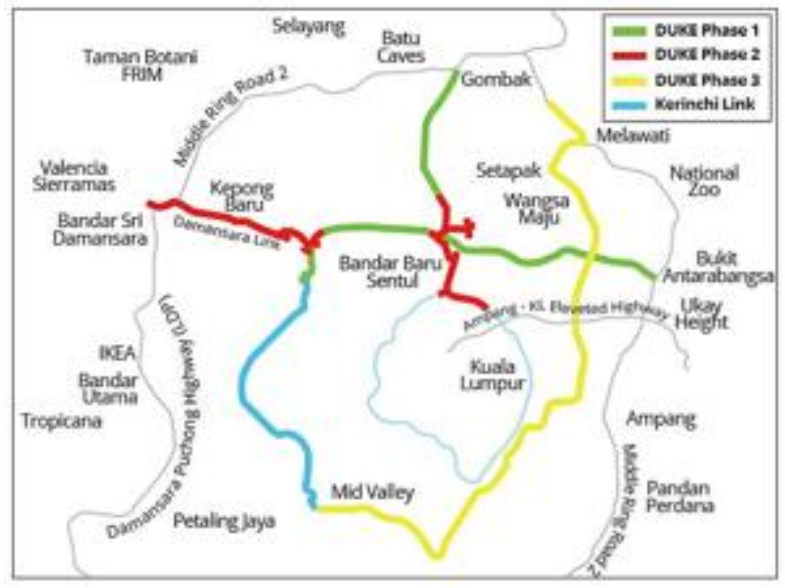

Fig. 4: Map showing urban Highways that connect the city of Kuala Lumpur with sub urban core-Damansara and Petaling Jaya (Source: http://vault.starproperty.my.s3.amazonaws.com/wp-content/uploads/2015/06/keeping_the_loop_free_of_jams_-_dukemap.png)

\subsection{Infrastructural Urbanism}

The interdependence between infrastructure and urban development has always been one of the most important topics of urban planning (Hauck and Kleinekort, 2011). Urban highways that cut through or surround city centre have become one of the most visible infrastructures. The state of urban highways and its implication towards the urban fabric have been discussed in many academic writings. In this context, three ideologies have been observed. First, the conventional perspective in which highways were built to urban spatial connectivity and continuity (Brandão and Brandão, 2017). Often, elevated highways of the first generation have little aesthetic value (Figure 5), which was built with steel and pre fab concrete (Samuel, 2006). Second, the urban planners that embraced the car-based concept as part of their design philosophy. Wright's Broadacre City and Le Corbusier's vertical garden city were attempted to promote the notion of scenic parkways (Hauck and Kleinekort, 2011). The contemporary and innovative conversion of highways and make it more likeable landscape represent the third ideologies. Figure 6 demonstrates prominent instances from the third ideologies that are evident at John Fitzgerald Expressway in Boston which have been replaced by the underground Central Artery vis-à-vis The Big Dig (Samuel, 2006) and the Cheonggyecheon Stream that revolutionized a traffic-fill stretch of elevated highway in Seoul (Marshall, 2016).

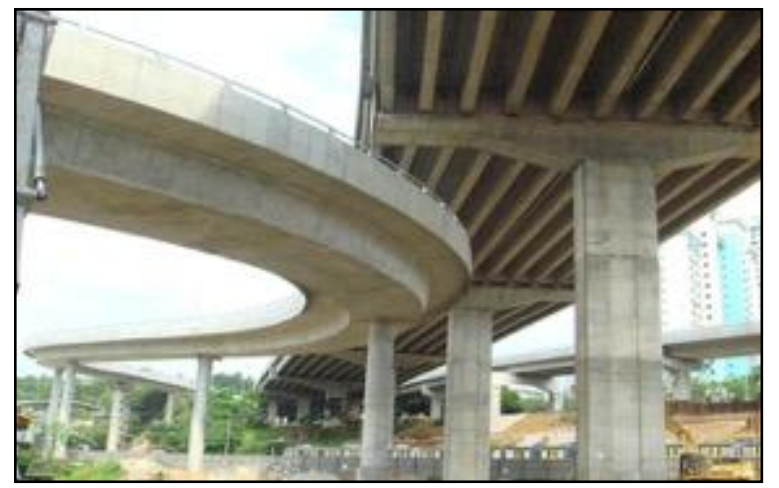

Fig. 5: The conventional highway design using pre-fab concrete demonstrates lack of aesthetic value (Source: $h$ ttp://www.tcpl.com/images/portfolio_one/klph.jpg) 


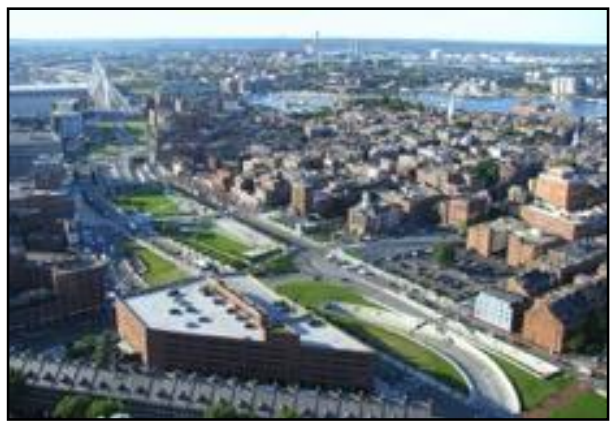

(a)

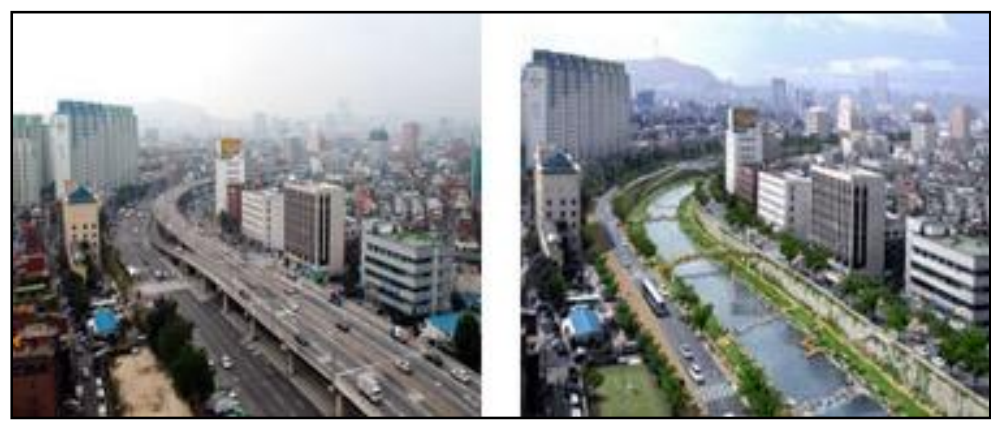

(b)

Fig. 6: Innovative highways-(a) The Big Dig, Boston and (b) the Cheonggyecheon Stream which was converted from elevated highway in Seoul

(Source: https://cityworksinc.files.wordpress.com/2012/09/img_0232.jpeg

http://www.globalrestorationnetwork.org/uploads/files/CaseStudyAttachments/123_seoul-1.jpg)

\subsection{Elevated highways and Urban spatial discontinuity}

The term 'elevated highway or expressway' and 'flyover' has interchangeably been used in academic writings. The former is often used in the context of United State of America (Samuel, 2006). The later, however, has commonly been accepted in the United Kingdom and most Commonwealth countries (Akinci et al. 2016). Throughout this paper, the term 'elevated highway' has been adopted by the authors. The function of elevated urban highways that could transfer and mobile people around cities is understandable. Conversely, the presence of this urban type infrastructure somehow generates specific spaces with idiosyncratic spatial characteristics (Hauck and Kleinekort, 2011). The emergence of undefined and unusable of spaces under highways viaduct has been increased, which disrupted the urban space's landscape system, land use and public areas (Akinci et al. 2016). The undefined and unusable spaces under the elevated highways often referred as "interstitial space" (Wall, 2011), "terrain vague" (Rico, 2011), "SLOAPS-Space leftover after planning, (Carmona, 2010), "gap spaces" (Hormingo and Morita, 2004), "wastelands", "derelict areas" (Doron, 2000) and "lost space" (Trancik, 1986).

According to Engwicht, (1990), the diminishing of the social exchange spaces in urban fabric is directly proportional to the increase in spaces for transport mobility. Elevated highways have often been built in the following urban areas: surround urban periphery, river bank, industrial area and the one that cut through the low-income housing (Bisecker, 2015). On the one hand, development of this kind infrastructure would primarily increase the accessibility and mobility of urban dwellers. On the other hand, it has physically become barriers that separate district or neighbourhood.

Saouma (2008) conducted a thorough analysis of the impact of elevated highways in the urban area. Her findings revealed six (6) types of impacts: [1] Symbol of progression, increase accessibility and mobility; [2] Dominant structure in urban fabric; [3] Segregate community or neighbourhood, become physical and psychological barrier and visual intrusion; [4] Produce undefined space which often misused; [5] Allow minimum natural lighting and poor ventilation at space under the elevated structure and [6] Generate negative spaces or lost spaces which always been neglected. The six impacts are shown in Figure 7.
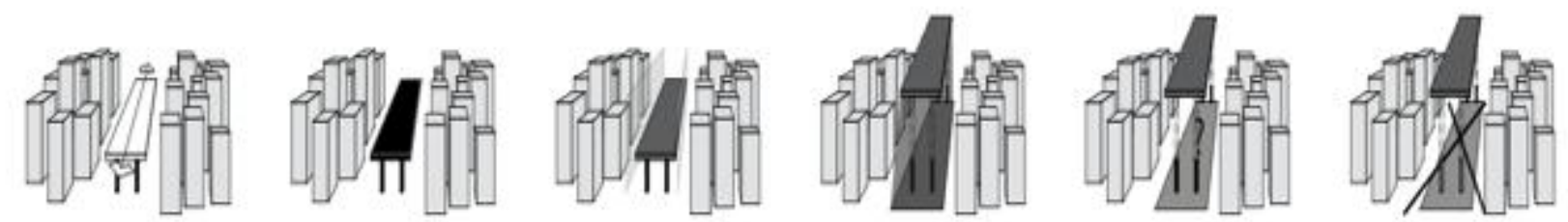

Fig. 7: The six impacts of elevated highways in urban areas as explored and illustrated by Saouma Source: Saouma (2008)

\subsection{The innovative approach to transform lost space to vibrant and usable space}

As mentioned in section 2.2, many researchers have shown interest and attempted to transform the leftover spaces caused by elevated highways. Hence, the work of Hormingo and Morita (2004) is worthwhile to mention. Despite the lost spaces which often associated with negative activities or characteristics and unstable, the duo has been optimistic about this issue. They emphasized on how the gap spaces generated by elevated railways can be explored to improve the urban system connectivity. Their conceptual idea behind the "gap spaces" is shown in Figure 8. 


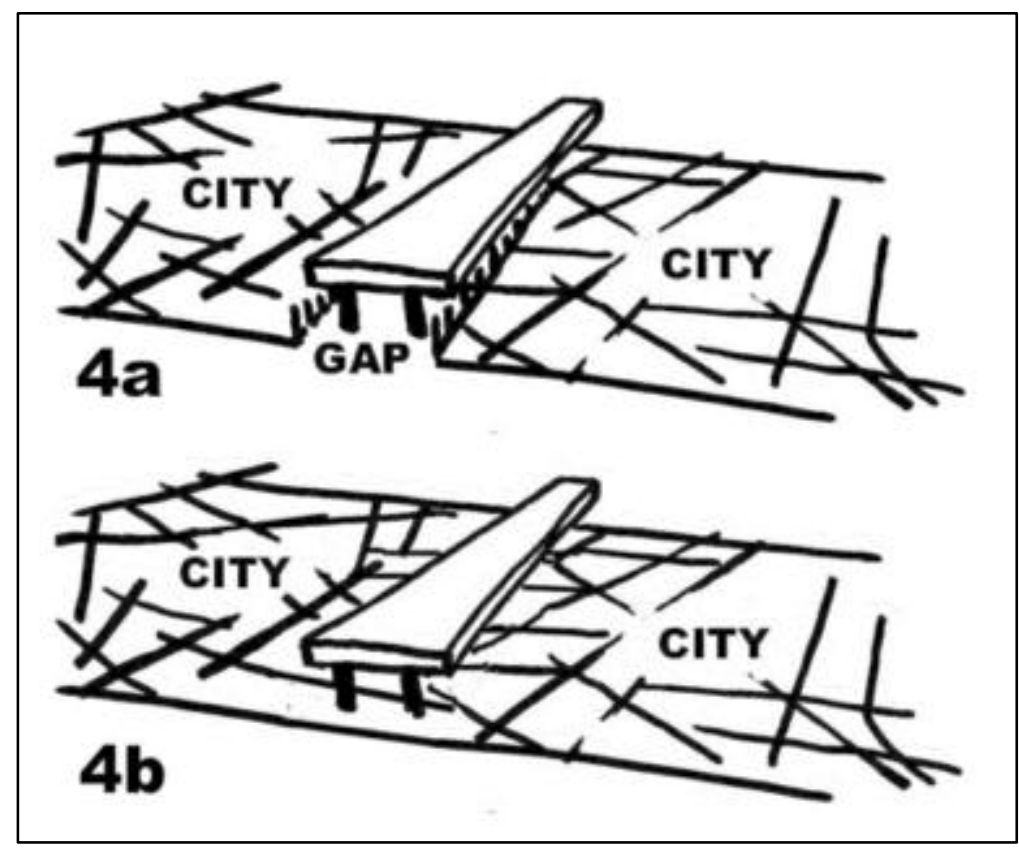

Fig. 8: Gapspaces generated by elevated highway/railway (4a) and through innovative design, the gap space shall be connected (4b) (Source: Hormingo \& Morita, 2004)

To what extent cities have altered spaces under the elevated highways, can be found in both academic writings and popular writing such as magazine, newspapers, and electronic media. In the Western context, the contemporary approach on how the leftover spaces have been transformed into vibrant spaces is evident in Hauck (2011), (Bjarke Ingels Group, 2011), and Roloff (2011). Asian researchers such as Ari Prasetyo and Martin-Iverson (2015) and Qamaruz-Zaman et al. (2012) have also exhibited curiosity in this topic. The former conducted study at the Pashupati flyover, a highway connecting Bandung to Jakarta, while the latter focused on the potential of activities at two flyovers in Kuala Lumpur-the MRR2 and Penchala Link. For the past three years, revitalization of spaces under the elevated structures has become one of an important topic in the Online journals related to architecture, landscape architecture and urban planning and design (Jaffe, 2015).

\subsection{Methodology and Focus of Study}

This research employs a case study which allows the authors to examine contemporary phenomenon within the real-life situation using the qualitative method. Site observation and data collection of the left-over spaces on site were guided by a systematic framework established by Frank (2011). The framework allowed the authors to document systematically the activities, location, time, characteristics, site adaptation as well as the status of the activity within the studied site. The observed variables were analysed and summarized as represented in Table 1. Duta Ulu Kelang Expressway or abbreviated as DUKE is one of the expressway possesses one of the longest span total elevated route amongst the highway in Kuala Lumpur, hence the selection of this site as a case study. It is elevated, primarily parts that run across dense urban communities and neighbourhoods resulting in the presence of multiple interstitial spaces. Diverse in form, these spaces share the common conditions of enclosure, emptiness and in some parts unclear function. Along the expressway, these byproducts are enclosed by large scaled infrastructural forms in contrasting scale to the void it holds below. The site of the case study is located underneath the DUKE highway near the Jalan Pahang ramp and Sentul Pasar Interchange (Figure 9). As of current, the surrounding major site context includes religious institutions - Jamiul Ehsan Mosque, commercial lots as well as a newly built mix residential tower - The Reach @ Titiwangsa. The findings of this particular study were limited to the observation of the site at the particular span of time. 


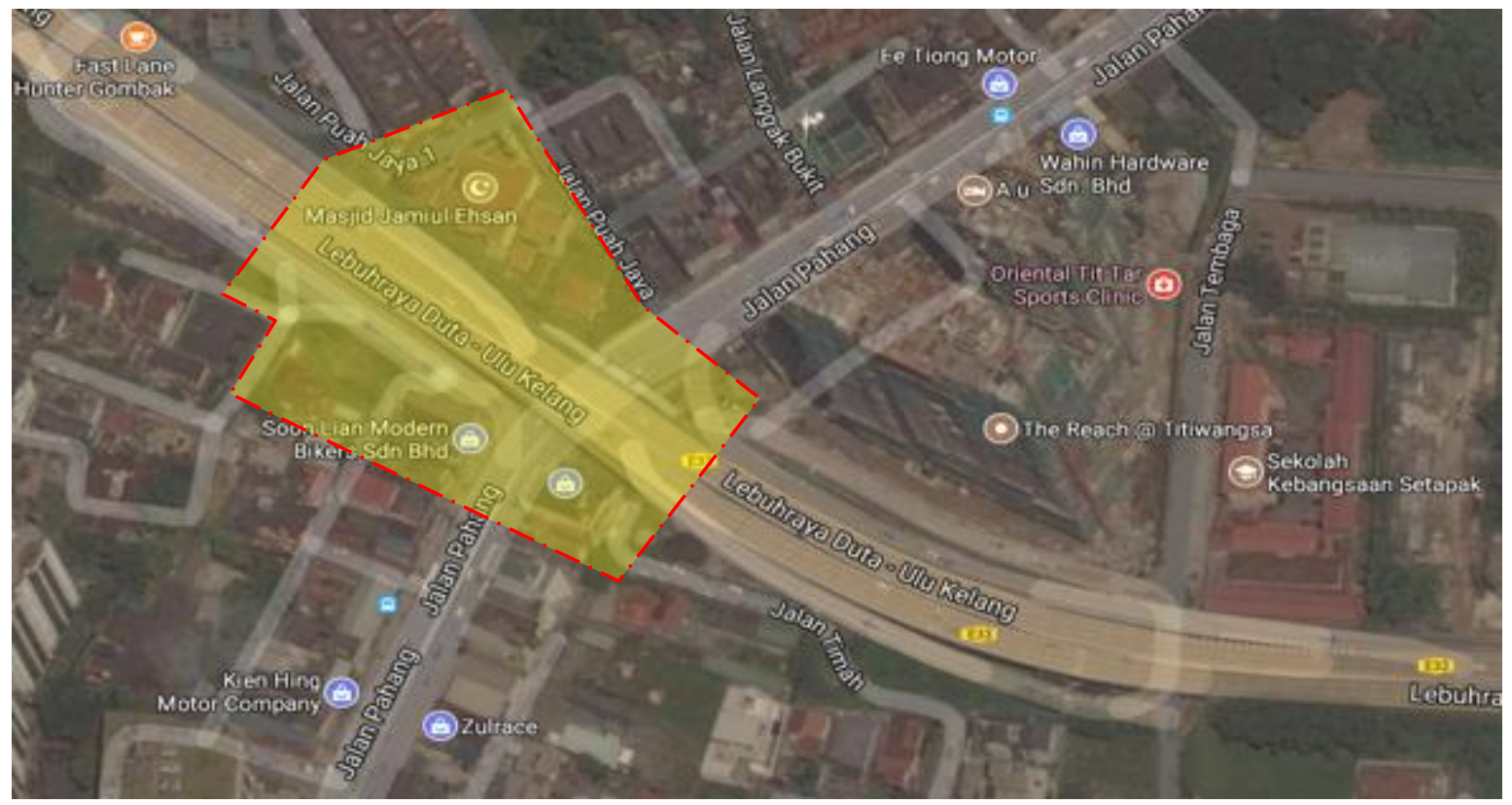

Fig. 9: Case Study location and context (Source: Google Maps)

\subsection{Case Study of DUKE Highway Phase 1: Jalan Pahang Ramp - Sentul Pasar Interchange}

DUKE Highway is an 18-km long highway spanning from Jalan Duta to Taman Hillview in Ulu Klang (Figure 10) and poseses one of the longest span total elevated route amongst the highway in Kuala Lumpur, hence the selection of this site as a case study. The highway began its initiation back in 2004, and DBKL conducted a detailed study of the alignment that feeds the next three years, including Environmental Impact Assessment and Public Opinion Duta-Ulu Klang Expressway (DUKE), E33, is the main expressway network in Klang Valley, Malaysia. The expressway was constructed to provide the essential linkage between New Klang Valley Expressway E1 (NKVE), Kuala Lumpur-Karak Expressway 2-E8 and Kuala Lumpur Middle Ring Road 2 (MRR2). The expressway used to be known as the Kuala Lumpur North East Expressway (KLNEE). It is the main element in the Kuala Lumpur Structure Plan 2020 as specified in the Transportation Research of the Japan International Cooperation Agency (JICA) conducted by the Kuala Lumpur City Hall (Dewan Bandaraya Kuala Lumpur) (DBKL) in 1985. Construction began in 2006 and was completed in 2009. Built to accommodate 120,000 vehicles per day, it was identified by DBKL as one of the main connecting routes to complete the Kuala Lumpur Structure Plan 2020. The Jalan Duta-DUKE Interchange was built at the sharp hairpin of the NKVE, and the Jalan Kuching Interchange was built at the former Jalan Kuching Toll Plaza owned by Kamunting Corporation Berhad. The route is currently being managed and maintained by EKOVEST Berhad. In addition to improving connectivity, DUKE disperses traffic from the city to the suburban range through several routes in and out of several branches of the main intersection.

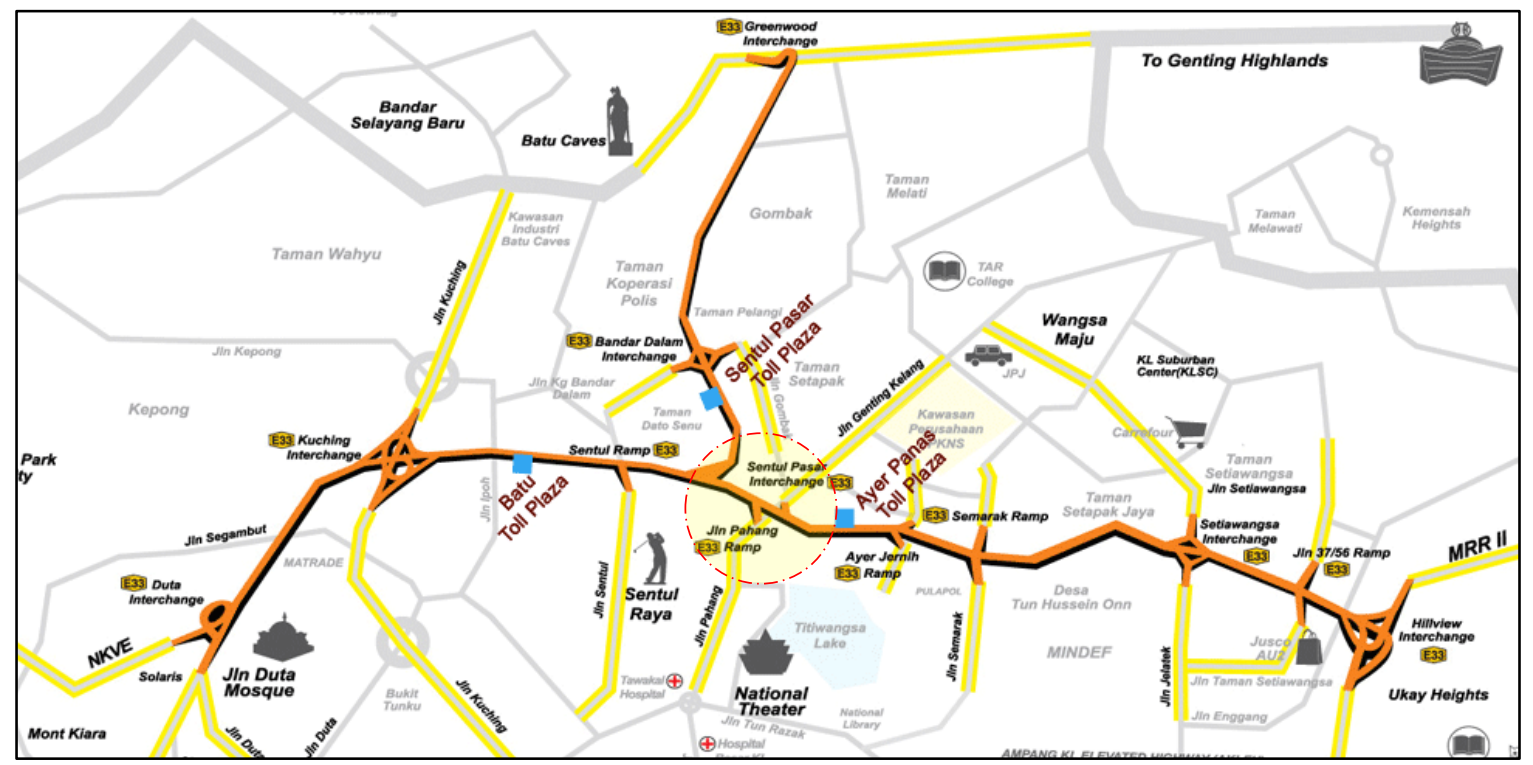

Fig. 10: DUKE highway map and location of the case study.

(Source: http://www.klia2.info/images/tools/highway-map-duke-highway-med.png) 


\subsection{Site Analysis.}

The activity recorded showcases various formal as well as informal activities within site. Sidewalks and roadside curbs were seen being used as informal spaces for commercial activities. Many of the social and spatial characteristics by the selling of food and beverages showcased a publicly owned, flat surface with a constant flow of passer by pedestrians (Figure 11 and 12). The time of occurrence usually starts in the morning and selling of food products is usually seized late in the evening as the site gets relatively dark and the number of pedestrians in the area dwindles. The commercial activity within site was deemed as informal and temporary as it lacks proper amenities such as kiosk, proper sitting area or tables. With regards to the legal status of the activity, it is regarded as illegal hence the "dilarang berjaja" signage. Apart from the space being used for selling of food products, the nature of the space which is covered by the overhead deck of the highway allowed the space to be utilized as a temporary shelter by pedestrians and motorcyclist from the rain (Figure 13). Other activities and use of space included informal but allowable parking sites; since no marking of proper parking lots was observed during the time of the fieldwork (Figure 14 and 15) and vehicles were observed and recorded being parked in unmarked open spaces. Vehicles were seen being parked here primarily during the daytime, and as night falls, space would be left empty, unused and unattended. The unclear function of the space also attracted illegal activities, as some parts of the spaces were recorded being utilized as illegal dumping sites (Figure 16 and 17).

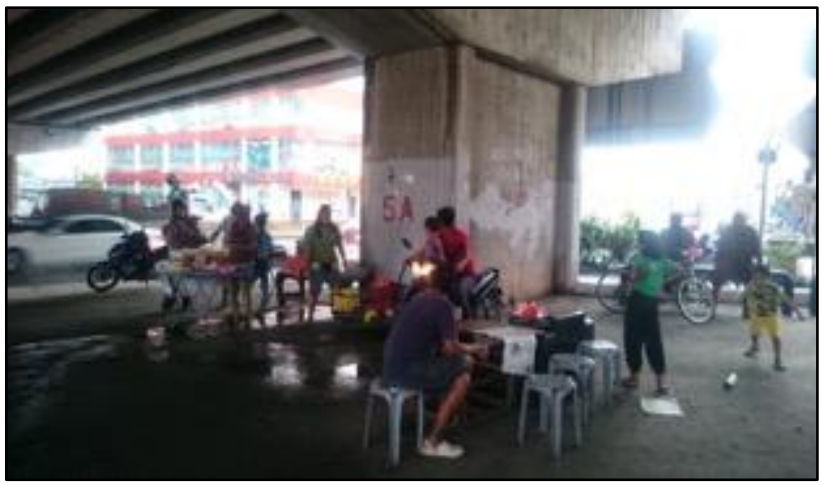

Fig. 11

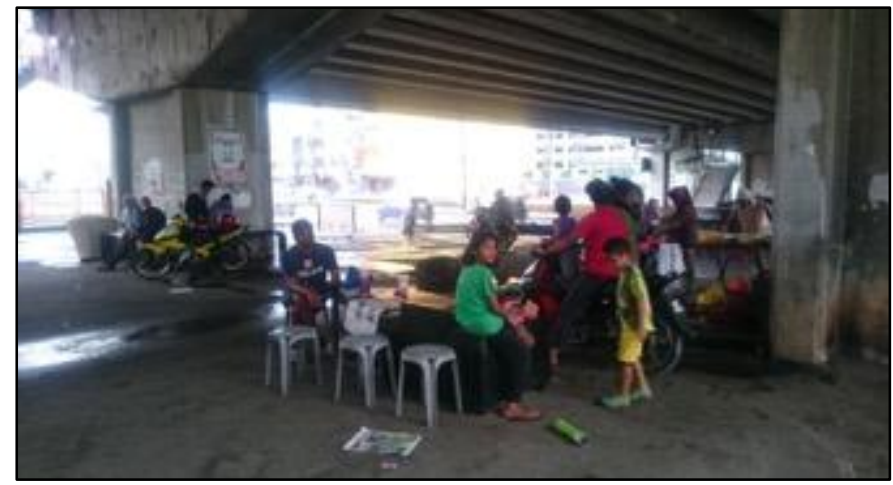

Fig. 12

Fig. 11 and 12: Selling of food and beverages underneath DUKE near the Jalan Pahang - Sentul Pasar Interchange

(Source: Author)

Table 1. Summary of the Site Analysis. DUKE - Jalan Pahang - Sentul Pasar Interchange

\begin{tabular}{|c|c|c|c|c|c|}
\hline Activity & Location & Time & Site Characteristics & Adaptation & Status \\
\hline Selling of food items & $\begin{array}{l}\text { Near roadside, on } \\
\text { road shoulder }\end{array}$ & $\begin{array}{l}\text { Daytime only, from } \\
\text { mid-morning to late } \\
\text { evening }\end{array}$ & $\begin{array}{l}\text { Adjacent to passing road } \\
\text { (Jalan Pahang) and } \\
\text { pedestrian ways }\end{array}$ & $\begin{array}{l}\text { Temporary, modular and non- } \\
\text { permanent tables and stools }\end{array}$ & $\begin{array}{l}\text { Illegal but sometimes } \\
\text { tolerated. Unclear }\end{array}$ \\
\hline Vehicular parking & $\begin{array}{l}\text { Inner part of the } \\
\text { space underneath } \\
\text { DUKE }\end{array}$ & $\begin{array}{l}\text { Daytime only. } \\
\text { Morning until late } \\
\text { evening. }\end{array}$ & $\begin{array}{l}\text { Expansive, unobstructed } \\
\text { surface, somewhat } \\
\text { secluded, dark. }\end{array}$ & $\begin{array}{l}\text { Some areas have wire fencing, } \\
\text { but no parking lot markings }\end{array}$ & $\begin{array}{l}\text { Tolerated, legal. Unclear } \\
\text { as space is not formal } \\
\text { parking area }\end{array}$ \\
\hline $\begin{array}{l}\text { Temporary shelter } \\
\text { from weather }\end{array}$ & $\begin{array}{l}\text { Near roadside } \\
\text { (Jalan Pahang) }\end{array}$ & $\begin{array}{l}\text { During rainy } \\
\text { weather. Day and } \\
\text { night }\end{array}$ & $\begin{array}{l}\text { Open space, permanent } \\
\text { sitting near elevated } \\
\text { highway's columns. }\end{array}$ & $\begin{array}{l}\text { Permanent sitting made from } \\
\text { galvanized steel pipe set up by } \\
\text { the local council to be used as } \\
\text { sitting/waiting area for } \\
\text { pedestrians }\end{array}$ & Tolerated. Legal \\
\hline Waste dumping & $\begin{array}{l}\text { Inner part of the } \\
\text { space underneath } \\
\text { DUKE }\end{array}$ & - & $\begin{array}{l}\text { Open space, secluded } \\
\text { area of the site. }\end{array}$ & - & Illegal \\
\hline
\end{tabular}

(Source: Author) 


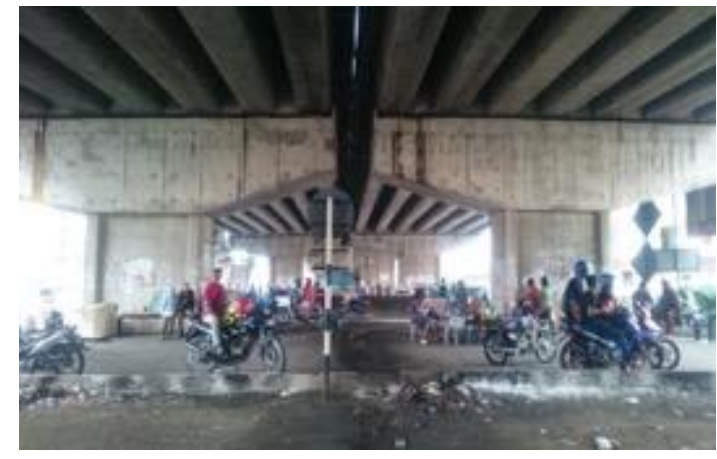

Fig. 13

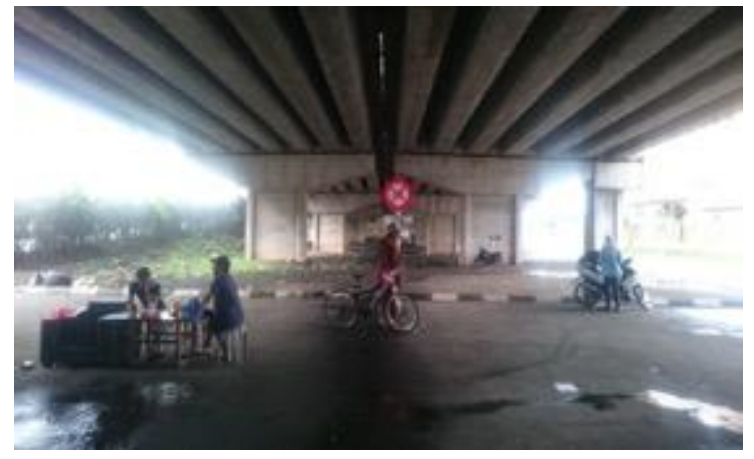

Fig. 14

Fig. 3.23 \& 3.24: Pedestrians and motorcyclist taking refuge from the rain underneath the highway. (Source: Author)

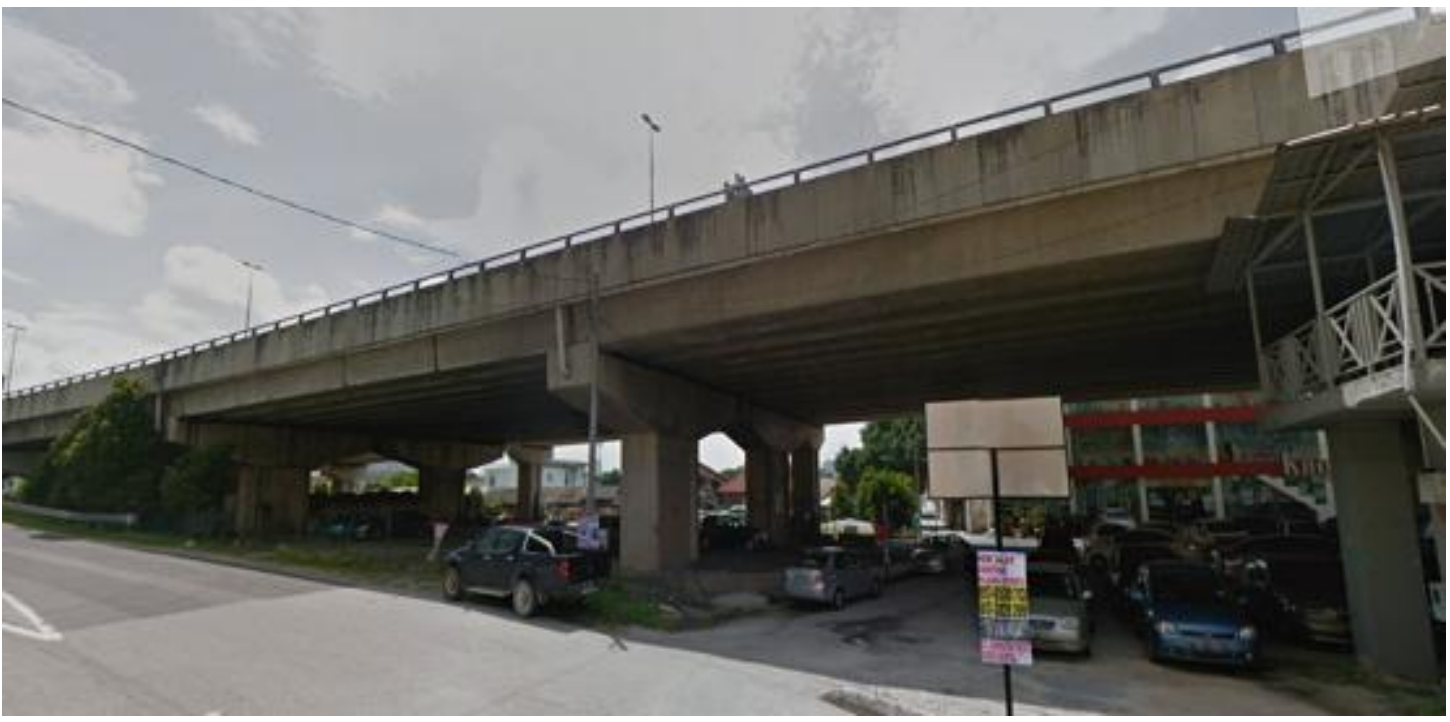

Fig. 15: Some parts of the space being used as an informal parking site. (Source: Author)
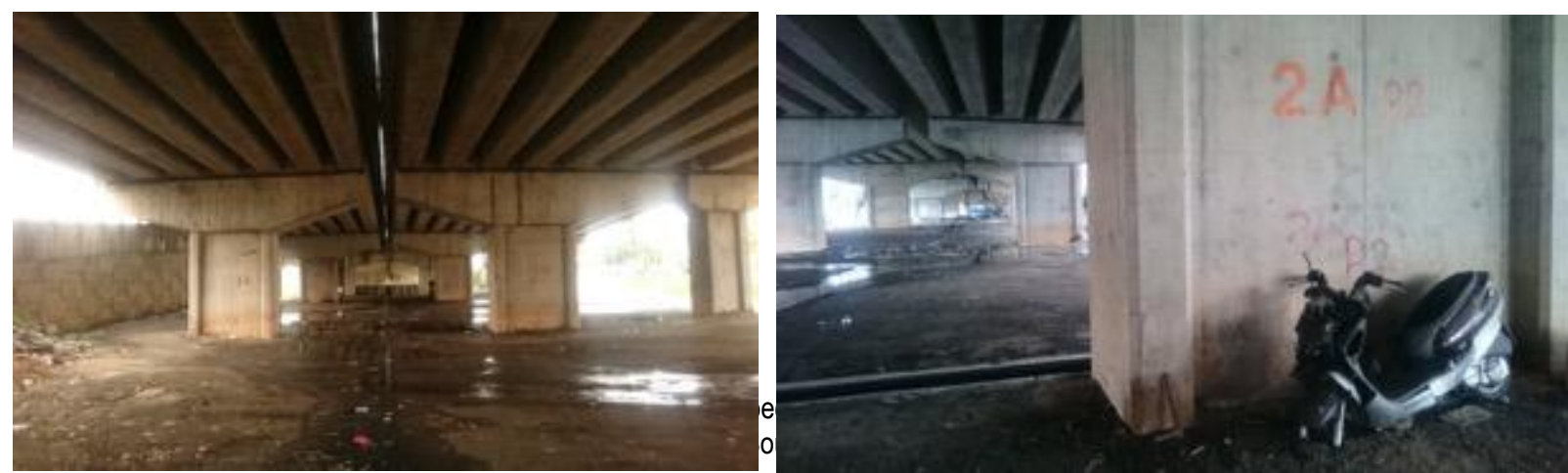

\subsection{Findings and Discussion}

The summary of the characteristics of the leftover spaces shown in Table 1 exposes similar characteristics to that of the study conducted by Saouma's in Beirut (2008). Dark and secluded are the primer character observed underneath the elevated highway. Following this, findings of this study can also be linked with research explored by Wall (2011). He discussed several key characteristics about the features of interstitial spaces located between or under elevated highways: they are small, irregular and enclosed. These characteristics can be associated with the spaces present within the area of the case study. In the case of DUKE - 
Jalan Pahang Ramp - Sentul Pasar Interchange, the notion of Wall's characteristics is observed present; the spaces are indeed small, irregular and enclosed. These spaces are made as small as possible, to balance with the need to minimize the area of land for the high capacity infrastructure while maximizing the efficiency of the system.

Through the site observation, it is also apparent that the available spaces under the structure are also irregular in form as they are definite to the forms of the overhead structure. The spaces are also enclosed on at least one side, and in this case, it is apparent that space is dominated on one side by the expressway. The sense of scale between the infrastructural network and the human activity is a contrasting site to view. Human scaled activities present at this site remain insignificant if it was to compare with the function of the massive structure positioned overhead. The discontinuation between the interstitial spaces supports the study conducted by Akinci et al. (2016) and Bisecker (2015), which highlight the contrast in scale between the structure and the adjacent neighbourhood. Adding to this, the massive form and high paced nature of the DUKE intensifies the juxtaposition of scale. Besides, the general characteristics of interstitial space as discussed by Wall (2011), the author furthermore highlighted that left-over spaces also generally appear to be undefined in use, ownership, management and function. The vacant spaces suggest ambiguity regarding specified use as well as function. These leftover spaces project a sense of abandonment and lost opportunities in contrast to the highly managed and planned infrastructure above it.

The characteristics observed from the case of DUKE puts forth several key issues and challenges, the fragmentary nature of these lines of infrastructure has sealed off the urban fabric that has minimal connection to the adjacent spaces. As described by SolaMorales (1995), these are spaces with unincorporated margins, interior islands void of activity, oversights; these areas are simply uninhabited, unsafe, un-productive. In a nutshell, they are foreign to the urban system, mentally exterior in the physical interior of the city, its negative image. As described in the KL Structure Plan 2020, infrastructures have caused adjacent spaces and areas or neighbourhoods to be divided and that they remain physically close but virtually inaccessible to each other. This key issue is significantly apparent through the observation of the case study. The lack of continuity at the ground level regarding support activities, scale as well as a definitive space function has caused severe vagueness regarding function and use of the space.

After careful examination of the case-study presented, it is clear that the case study of the Jalan Pahang - Sentul Pasar Interchange under the DUKE possess such characteristics as so often described in various kinds of literature pertaining the topic of left over spaces as a result of infrastructural development. The apparent situation calls for a reconsideration of the design discipline and paradigm as mentioned by Rico (2011), where the author argues that these spaces need to be critically assessed regarding its spatial effects, bio-political production as well as functional performance. The infrastructural landscape has been widely discussed throughout the latter half of the 20th century, with various terms coined to describe the emptiness associated with their low level of accessibility as well as the potentials that they open for designers (Lerup, 2000; Sola-Morales, 1995).

Many cities across the world including Kuala Lumpur feature vast quantities of open, fragmented spaces with an urban fabric that is made of disconnected patches and large areas of vacant land. Poor planning systems, wasteful and disorderly urban expansion, land speculation, and various forms of sprawl are the main factors behind such fragmentation. Both built and natural environments are affected by these practices that work against environmental sustainability and the ecology of open spaces inside cities (Angel and Civco 2012). Various other cities suffer from unused or undeveloped areas that often include vacant lands or properties in undesirable locations or in prime areas that are prone to speculation and missuses.

One such approach to address this issue is through Planned City Infills $(\mathrm{PCl})$. $\mathrm{PCl}$ can act as effective remedies to these problems in cities with low densities, various forms of segregation, poor connectivity and inefficient use of existing infrastructure. The approach is a very powerful lever for change through "filling up space gaps" (Sustainable Cities Institute 2016) achieves an urban structure that reduces spatial ambiguity, optimizes land use and helps preserve and organize open spaces (UN-Habitat 2016). It is argued that, through the new urban agenda, planned city infills have the potential to transform central and middle urban areas into vibrant places for a more intense community life, as existing vacant sites and underused areas are (re)developed or re-used (The City of Sacramento 2016). Arrays of possibilities opened up through the adaptive use are seen at the Big Dig, Boston and the reclamation of the Cheonggyecheon River in Seoul. These instances portray how the obsolete or underused urban infrastructure through innovative design have been salvaged into green infrastructure for walking and biking, informal play and exercise, and social interaction while offering a distributed strategy for urban runoff infiltration and habitat provision (Wolch et al. 2014). These green spaces are unlikely to offer organized recreational activities, but they can be creatively utilized if designed and planned in a way that would support possible spatial usage.

\subsection{Conclusion and Recommendations}

The findings of this study contribute to a better understanding of the impact of the elevated highway at the case study. The analysed literature has supported argument about the extent which satellite city in modern urban planning has contributed to the rapid development of elevated urban highways. Although the presence of elevated highway at the study area has increased connectivity and mobility among city dwellers, the emergence of leftover spaces has also contributed to discontinuity of urban spaces. The leftover spaces found under the elevated highway are small, irregular and enclosed, which demonstrate fragmented urban spaces with unclear function. Adding to this, the occurrence of elevated highway has validated issue related to infrastructure which caused adjacent spaces that are often inaccessible mentioned in the Kuala Lumpur Structure Plan 2020.The urban fabric and its spaces shall be perceived as a system that is well integrated and efficiently functioned. Hence, the proactive steps should be taken into consideration by landscape architects, 
architects, planners and designers alike. The challenges associated with these types of spaces shall be viewed from a different perspective. The existence of leftover spaces at the study area of should be taken as opportunities to reimagine and reinstate the spaces as a form of urban connector. These interstitial spaces could be transformed into a space that supports human scaled activities as a direct contrast to the vehicular scaled activities right above it. The suggested approach through $\mathrm{PCl}$ seems feasible as an effective remedy for redesigning the unused spaces which could transform into a meaningful place with a sense of belonging and attachment. Suggestions for future study could include a prolonged observation of a particular site whilst including feedbacks and inputs from local users and surrounding communities in order to extend the value of the study as well as provide a more wholistic understanding of a particular site.

\section{Acknowledgement}

This research received funding from the LESTARI Grant (Project Code: 600-RMI/DANA 5/3/LESTARI O(85/2015), which is provided by The Institute of Research Management and Innovation (IRMI), Universiti Teknologi MARA, Shah Alam Selangor.

\section{References}

Akinci, Y. C., Demir, S., \& Demirel, O. (2016). Landscape Architecture and Creating Innovative Spaces under Highway Overpasses. In book: Environmental Sustainability and Landscape Management, Chapter: 1, Publisher: ST. Kliment Ohridski University Press, Editors: Recep Efe, İsa Cürebal, Abdalla Gad, Brigitta Tóth, pp.1-10

Angel, S. \& D. Civco. (2012) The fragmentation of urban landscapes: global evidence of a key attribute of the spatial structure of cities, 1990-2000. Environment and Urbanization 24 (1):249-283

Barter, P., (2004). Transport, urban structure and 'lock-in' in the Kuala Lumpur Metropolitan Area. International Development Planning Review, 26(1), pp.1-24.

Biesecker, C. (2015). Designing urban underhighway spaces. PhD dissertation, University of Georgia.

Bjarke Ingels Group, (2011). Slussen, Social Infrastructure. In T. Hauck, R. Keller, \& V. Kleinekort (Eds.), Infrastructural Urbanism Addressing the In- between (pp. 241). Berlin: DOM Publishers.

Brandão A. L. \& Brandão P. (2017). Public Space, Infrastructure, Landscape: an interdisciplinary matrix for urban spatial continuity, The Journal of Public Space, 2(1), 123-134, DOI: $10.5204 / j p s . v 211.55$

Bürgi, M., Hersperger, A. M., \& Schneeberger, N. (2005). Driving forces of landscape change-current and new directions. Landscape ecology, 19(8), 857-868.

Canters, K. (1997). Habitat fragmentation and infrastructure: proceedings of the International Conference,'Habitat Fragmentation, Infrastructure and the Role of Ecological Engineering': 17-21 September 1995, Maastricht-The Hague, The Netherlands. In Habitat Fragmentation, Infrastructure and the Role of Ecological Engineering, Conference, 1995, Maastricht and The Hague, Netherlands.

Clements, G. R. (2013). The environmental and social impacts of roads in Southeast Asia (Doctoral dissertation, James Cook University).

Carmona, M. (2010). Public Places, Urban Spaces: The Dimensions of Urban Design. Routledge.

Crisman, P. 2009. Inhabiting the in-between: architecture and infrastructure intertwined. Site Out of Mind. University of Virginia School of architectures.

Dasimah, O. 2001. New towns development and the quality of life in Malaysia. Sixth Southeast Asian Geographers SEAGA 6 Conference.

Doron, G. (2000). The dead zone and the architecture of transgression. City, 4, 2 247-263

Engwicht, D. (1999). Street Reclaiming: Creating Livable Streets and Vibrant Communities. Philadelphia, PA: New Society Publishers.

Forman, R. T., Sperling, D., Bissonette, J. A., Clevenger, A. P., Cutshall, C. D., Dale, V. H., \& Winter, T. C. (2003). Road Ecology: Science and Solutions. Island Press.

Franck, K. A. (2011). Occupying the Edge and the Underneath- "Other" Urban Public Spaces. In T. Hauck, R. Keller, \& V. Kleinekort (Eds.), Infrastructural Urbanism Addressing the In- between (pp. 117-129). Berlin: DOM Publishers.

Lerup, L. (2000) After the City. MIT Press, Boston.

Gee, T.M., ( 2002). Jalan, Jalan: Invading, destroying and reconstructing the Southeast Asian city. Bijdragen tot de Taal-, Land-en Volkenkunde, 158(4), pp.637-652.

Gullick, J. M. (2000). A history of Kuala Lumpur 1857-1939. Petaling Jaya, Selangor Darul Ehsan, Malaysia: Falcon Press.

Halprin, L. (1966). Freeways. New York: Reinhold Publishing Co.

Hamersma, M., Heinen, E., Tillema, T. \& Arts, J., (2017). The development of highway nuisance perception: Experiences of residents along the Southern Ring Road in Groningen, The Netherlands. Land Use Policy, 61, pp.553-563.

Harnack, M., \& Kohler, M. (2011). As found. Use, meaning and re-appropriation of contentious urban spaces. Infrastructural urbanism-Addressing the in-between, 131 144. 
Hauck, T. \& Kleinekort, V. (2011). Infrastructural Urbanism. In T. Hauck, R. Keller, \& V. Kleinekort (Eds.), Infrastructural Urbanism Addressing the In- between (pp. 917). Berlin: DOM Publishers.

Hauck, T. (2011). Burnside and DIY Skatepark Movement, In T. Hauck, R. Keller, \& V. Kleinekort (Eds.), Infrastructural Urbanism Addressing the In- between (pp. 171180). Berlin: DOM Publishers.

Hormigo, P. \& Morita, T., (2004). Urban gapscapes: problems and opportunities in urban design analysis of gap spaces originated by elevated railways. Journal of Asian Architecture and Building Engineering, 3(1), pp.181-188.

Jaffe, E. (2015). Reviving the Dead Space Under Elevated Structures. https://www.citylab.com/design/2015/06/bringing-the-dead-spaces-under-an-elevated-back-tolife/396236/. Latest accessed 25/08/2017

Jane, J. (1961). The Death and Life of Great American Cities. New-York, NY: Vintage.

Lawson, W. (2017). The Woman Who saved New York City From Superhighway Hell. https://www.vanityfair.com/culture/2017/04/jane-jacobs-citizen-jane-documentary. : Latest accessed 25/08/2017

Marshall, C. (2016). Story of cities \#50. The Reclaimed Stream Bringing Life to the Heart of Seoul. https://www.theguardian.com/cities/2016/may/25/story-citiesreclaimed-stream-heart-seoul-cheonggyecheon. Latest accessed 25/08/2017

Merrilees, B., Miller, D., \& Herrington. C. (2013). City Branding: A Facilitating Framework for Stressed Satellite Cities. Journal of Business Research 66. Pp 37-44

Meyer, W. B., and B. L. Turner II. 1994. Changes in land use and land cover: a global perspective. Cambridge University Press, Cambridge, UK.

Mohamad, J. \& Kiggundu, A.T., (2007). The rise of the private car in Kuala Lumpur, Malaysia: Assessing the policy options. IATSS research, 31(1), pp.69-77.

Mossop, E. (2006). Landscapes of Infrastructure. In The Landscape Urbanism Reader (pp. 163-178). New York: Princeton Architectural Press.

National Research Council. ( 2002). Surface Transportation Environmental Research: A Long- Term Strategy. National Academy Press, Washington, D.C., USA.

Nor, A. (2001). Urban development and the need for highways: assessing social impacts of bisected communities in Kuala Lumpur, Malaysia, National Geographical Conference 2001, Department of Geography, University of Malaya, Kuala Lumpur.

Pelan Struktur Kuala Lumpur (2020). Dewan Bandaraya Kuala Lumpur. www.dbkl.gov.my/pskl2020/.

Prasetyo, F.A. \& Martin-Iverson, S., (2015). Playing under the fly over A collaborative creative community in Bandung. Procedia-Social and Behavioral Sciences, 184, pp.30-39.

Pu Miao, (1990). Seven Characteristics of Traditional Urban Form in Southeast China. chromeextension://oemmndcbldboiebfnladdacbdfmadadm/http://iaste.berkeley.edu/pdfs/01.2d-Spr90miao-sml.pdf. Latest accessed 25/08/2017

Qamaruz-Zaman, N., Samadi, Z., \& Azhari, N.F.N. 2013. Under the flyovers of Kuala Lumpur: User centred activities in leftover spaces. Journal of Asian Behaviour Studies, 3(10), 89-103.

Rico, E. (2011) The Role of Infrastructural Landscape Within the Image of the City. In Infrastructural Urbanism: Addressing the In-Between. DOM Publishers, Berlin.

Roloff, J. (2011). I-5 Colonnade park. In T. Hauck, R. Keller, \& V. Kleinekort (Eds.), Infrastructural Urbanism Addressing the In- between (1st ed., pp.145-158) Berlin: DOM Publishers.

Sahabuddin, M. F. (2011). "Density form and transportation." inspired by 'what is lost space' (Roger Trancik, 1986). The University of Edinburgh. Edinburgh School of Architecture and Landscape Architecture (ESALA).

Sola-Morales, I. R. (1995) Terrain Vague. In Anyplace. Cambridge. MA. MIT Press.

Samuel, P. (2006). Innovative Roadway Design: Making Highways More Likeable. Policy Study 348, Los Angeles: Reason Foundation. http://www.reason.org/ps348.pdf. Latest accessed 25/08/2017

Sanches, P.M. \& Pellegrino, P.R.M., (2016). Greening potential of derelict and vacant lands in urban areas. Urban Forestry \& Urban Greening, 19 , pp.128-139.

Shoaib, H. \& El Gendy, N., (2013). Infrastructures: possibilities and potentials in reclaiming public space. Democratic Transition and Sustainable Communities, p.365.

Souma, R. (2008) When a city embraces its paradoxes: exploring the potential of public spaces under elevated highways: a case study in Bourj Hammoud, Beirut. Master's Thesis. Wageningen University. Wageningen, Netherlands.

Sustainable Cities Institute (2016). Planning urban infill, http://www.sustainablecitiesinstitute.org/topics/ land-use-and-planning/urban-infill-and-brownfieldsredevelopment, last accessed 12 April 2016

The City of Sacramento (2016). 'Infill', http://www.cityof- sacramento.org/Community-Development/Planning/ Long-Range/Infill.

Trancik, R. (1986). Finding Lost Space; Theories of Urban Design. New York: Van Nostrand Reinhold.

UN Habitat. (2016). World Cities Report 2016. UN-Habitat, Nairobi

Wall, E. (2011) Infrastructural Form, Interstitial Spaces and Informal Acts. In Infrastructural Urbanism: Addressing the In-Between. DOM Publishers, Berlin. 
Mohamed Anuar, M.I.N., \& Ahmad, R., / 3rd AQoL2017Kuching, 14-16 Oct 2017 / E-BPJ, 2(6), Nov 2017 (p.279-291)

Wolch, J. R., Byrne, J., \& Newell, J. P. (2014). Urban green space, public health, and environmental justice: The challenge of making cities 'just green enough'. Landscape and Urban Planning, 125, 234-244. 